\title{
Inhibition of Pythium spp. and Suppression of Pythium Blight of Turfgrasses with Phosphonate Fungicides
}

\author{
Phillip J. Cook, Peter J. Landschoot, and Maxim J. Schlossberg, Department of Crop and Soil Sciences, The \\ Pennsylvania State University, University Park 16802
}

\begin{abstract}
Cook, P. J., Landschoot, P. J., and Schlossberg, M. J. 2009. Inhibition of Pythium spp. and suppression of Pythium blight of turfgrasses with phosphonate fungicides. Plant Dis. 93:809-814.

Pythium aphanidermatum and other Pythium spp. cause Pythium blight of turfgrasses in the United States. Phosphonate fungicides suppress Pythium blight when applied preventatively, but efficacy may vary with product, rate and timing of application, and host species. The objectives of this study were to assess the inhibitory effects of phosphorous acid on Pythium spp. in vitro, and determine if active ingredient and formulation of phosphonate fungicides provide similar levels of Pythium blight suppression on perennial ryegrass and creeping bentgrass when applied at equivalent rates of phosphorous acid. Phosphorous acid $\mathrm{EC}_{50}$ values (effective concentration that reduces mycelial growth by 50\%) for P. aphanidermatum isolates ranged from 35.6 to 171.8 $\mu \mathrm{g} / \mathrm{ml}$. EC ${ }_{50}$ values for isolates of six other Pythium spp. were between 38.7 and $220.8 \mu \mathrm{g} / \mathrm{ml}$. In 2004 and 2005, all phosphonate treatments provided significant suppression of Pythium blight symptoms on creeping bentgrass and perennial ryegrass relative to the untreated control. No differences in percentage of blighted turf occurred among phosphonate treatments when applied at equivalent rates of phosphorous acid in either year of the study, regardless of active ingredient, formulation, or turfgrass species.
\end{abstract}

Pythium blight, caused by Pythium aphanidermatum (Edson) Fitzp. and other Pythium spp., is a destructive foliar disease of turfgrasses in many areas of the United States. In northern climates, this disease occurs on poorly drained perennial ryegrass (Lolium perenne) and creeping bentgrass (Agrostis stolonifera) golf course fairways during periods of high temperature and humidity $(13,16)$. Golf course superintendents typically manage Pythium blight using cultural practices and applications of fungicides when conditions favor disease development (23). Mefenoxam, propamocarb, azoxystrobin, pyraclostrobin, and the phosphonates are effective in controlling Pythium blight when applied prior to symptom development $(4,19$, 20,23).

Phosphonate fungicides are composed of the esters or salts of phosphorous acid $\left[\mathrm{HPO}(\mathrm{OH})_{2}\right]$, and most have fosetyl-Al or potassium phosphite as active ingredients (12). Phosphonate fungicides control many diseases caused by Phytophthora spp., Pythium spp., and some other plant pathogens. Unique properties of these fungicides include significant translocation in xylem and phloem, and a dual mode of action that

Corresponding author: P. J. Landschoot

E-mail: pj11@psu.edu

Accepted for publication 21 April 2009.

doi:10.1094/PDIS-93-8-0809

(c) 2009 The American Phytopathological Society involves direct fungitoxic effects and stimulation of certain host defense responses (12).

Although considerable research has been conducted on the fungitoxic effects of phosphonate fungicides on Phytophthora spp., relatively few studies have been carried out on species of Pythium. Sanders et al. (15) found no mycelial inhibition of 25 isolates of Pythium representing eight species on potato dextrose agar (PDA) amended with fosetyl-Al at 1, 10, and 100 $\mu \mathrm{g} / \mathrm{ml}$. Fenn and Coffey (11) reported that mycelia of four Pythium species were inhibited when phosphorous acid was amended into corn meal agar (CMA) at concentrations of 276 and $552 \mu \mathrm{g} / \mathrm{ml}$. The authors noted considerable variation in growth responses among the four species at low phosphorous acid concentrations, with $P$. aphanidermatum inhibited and $P$. ultimum stimulated at $69 \mu \mathrm{g} / \mathrm{ml}$. In a separate experiment, Fenn and Coffey (11) found one isolate of $P$. aphanidermatum was more strongly inhibited at $69 \mu \mathrm{g} / \mathrm{ml}$ phosphorous acid in the presence of 0.84 $\mathrm{mM}$ phosphate compared with $8.4 \mathrm{mM}$ phosphate. Detailed information is needed on the reaction of a range of Pythium spp. and isolates to varying concentrations of phosphorous acid in vitro.

Field studies comparing phosphonate fungicides for Pythium blight control have been conducted at different locations and on different turfgrass species $(4,8,9,19$ 22). In most of these studies, both fosetyl$\mathrm{Al}$ and potassium phosphite products reduced Pythium blight symptom develop- ment; however, in some cases, results varied depending on the product $(21,22)$, product rate $(21,22)$, and application timing $(9,19)$. In many of these studies, phosphonate products were not compared at equivalent concentrations of phosphorous acid. Because of potential efficacy and price differences among the active ingredients and formulations of phosphonate fungicides, golf turf managers would benefit from comparisons of phosphonate products applied at the same concentration of phosphorous acid and on different turfgrass species.

The objectives of this study were to assess the range of inhibitory effects of phosphorous acid on mycelial growth of different species and isolates of Pythium, and to determine if active ingredient and formulation of phosphonate fungicides provide similar suppression of Pythium blight in the field when applied at equivalent rates of phosphorous acid on perennial ryegrass and creeping bentgrass.

\section{MATERIALS AND METHODS}

Pythium isolates. $P$. aphanidermatum isolates were obtained from a collection maintained in the Department of Plant Pathology at the Pennsylvania State University by W. Uddin. Isolates of other $P y$ thium spp. ( $P$. graminicola, $P$. irregulare, and $P$. ultimum) were supplied by C. Stiles from a study conducted in Florida (18) or from a collection maintained by $\mathrm{G}$. Moorman at the Pennsylvania State University ( $P$. irregulare, $P$. ultimum, and $P$. myriotylum). One isolate of $P$. volutum and two isolates of $P$. torulosum were provided by L. Tredway, North Carolina State University, and J. Kerns, University of Wisconsin. Pythium spp., isolate designation, state of origin, year of isolation, and host (if known) for individual isolates are listed in Table 1. All isolates were maintained on slants of PDA (BBL, Becton, Dickson, and Co., Sparks, MD) and covered with autoclaved mineral oil. Isolates were transferred to new PDA slants every 3 months.

In vitro experiments with phosphorous acid, phosphoric acid, and mefenoxam. In vitro experiments were conducted to assess the effects of different concentrations of phosphorous acid and phosphoric acid $\left(\mathrm{H}_{3} \mathrm{PO}_{4}\right)$ on mycelial growth of 23 isolates of $P$. aphanidermatum, $P$. graminicola, $P$. irregulare, $P$. myriotylum, $P$. torulosum, $P$. ultimum, and $P$. volutum, and of mefenoxam concentrations on seven isolates of $P$. aphanidermatum. 
Phosphorous acid solutions were preagent-grade phosphorous acid (SigmaAldrich, St. Louis, MO) to a $\mathrm{pH}$ of 6.2 by titrating with $10 \mathrm{M}$ reagent-grade potassium hydroxide (KOH, Sigma-Aldrich) (5). Phosphoric acid solutions were made by adjusting a $1 \mathrm{M}$ solution of reagentgrade phosphoric acid (Sigma-Aldrich) to a pH of 6.2 by titrating with $10 \mathrm{M}$ reagentgrade potassium hydroxide. These solutions were used to amend CMA (BBL, 17 $\mathrm{g} /$ liter) with $10,50,100,500$, and 1,000 $\mu \mathrm{g} / \mathrm{ml}$ phosphorous acid or equivalent concentrations of phosphoric acid. Phosphoric acid treatments were used as controls to account for the potential inhibitory effects of potassium hydroxide, which was used to adjust the $\mathrm{pH}$ of the phosphorous acid. Technical-grade mefenoxam (Syngenta Professional Products, Greensboro, NC) was dissolved in acetone and amended into CMA at $0.01,0.1,1,10$, and $100 \mu \mathrm{g} / \mathrm{ml}$. Mefenoxam was dissolved in $2 \mathrm{ml}$ of acetone per liter of medium for each concentration. A preliminary test showed that 2 $\mathrm{ml}$ of acetone per liter of CMA did not influence growth of $P$. aphanidermatum when compared with nonamended CMA. Corn meal agar not amended with phosphorous acid, phosphoric acid, or mefenoxam served as another control.

All Pythium isolates selected for the in vitro study were maintained on nonamended CMA at $25^{\circ} \mathrm{C}$ for $30 \mathrm{~h}$ prior to transferring. Agar plugs, 7-mm-diameter, were cut from actively growing margins of each colony and transferred to the center of plastic 90-mm-diameter petri dishes containing CMA amended with phosphorous acid, phosphoric acid, or mefenoxam, pared by adjusting a $1 \mathrm{M}$ solution of re-

as well as the nonamended CMA. The petri dishes were incubated in the dark at $25^{\circ} \mathrm{C}$. Two replicates were used for each treatment, and treatments were arranged in a randomized complete block design. Radial growth was determined by measuring the colony radius at two points on each dish and recording the average value. Radial growth measurements were taken $30 \mathrm{~h}$ after transfer for all isolates of $P$. aphanidermatum, $P$. irregulare, $P$. myriotylum, and $P$. ultimum; $72 \mathrm{~h}$ after transfer for $P$. torulosum isolates; and $96 \mathrm{~h}$ after transfer for $P$. volutum and $P$. graminicola isolates. Percent relative growth was calculated as (radial growth on amended media/radial growth on nonamended media) $\times 100$. The experiment was performed twice, and data from both runs were similar. Thus, data were pooled for regression analysis.

Phosphorous acid $\mathrm{EC}_{50}$ values (effective concentration that reduces mycelial growth by $50 \%$ ) for all 23 Pythium isolates, and mefenoxam $\mathrm{EC}_{50}$ values for seven isolates of $P$. aphanidermatum, were obtained by regressing relative growth against the $\log _{10}$ of phosphorous acid or mefenoxam concentrations (SAS 9.1; SAS Institute, Cary, $\mathrm{NC}) . \mathrm{EC}_{50}$ values were not determined for phosphoric acid treatments because none of the concentrations inhibited growth of isolates relative to the nonamended CMA control.

Suppression of Pythium blight with potassium phosphite, fosetyl-Al, and mefenoxam. This field study was conducted at the Joseph Valentine Turfgrass Research Center, University Park, PA during 2004 and 2005. The soil at the test site is a Hagerstown silt loam with a $\mathrm{pH}$ of 6.8 , $168.1 \mathrm{~kg} / \mathrm{ha}$ Mehlich-3 P, 0.54 meq K/100

Table 1. Species, isolate, isolate origin, collection date, and host of Pythium isolates used in in vitro or field studies

\begin{tabular}{|c|c|c|c|c|}
\hline Pythium species & $\begin{array}{l}\text { Isolate } \\
\text { designation }\end{array}$ & Origin & $\begin{array}{c}\text { Year } \\
\text { collected }\end{array}$ & Host species \\
\hline P. aphanidermatum & $\mathrm{P}-3$ & PA & 1974 & Unknown \\
\hline P. aphanidermatum & P-20 & PA & 1975 & Unknown \\
\hline P. aphanidermatum & P-27 & PA & 1976 & Unknown \\
\hline P. aphanidermatum & P-32 & PA & 1986 & Unknown \\
\hline P. aphanidermatum & P-38 & PA & 1988 & Unknown \\
\hline P. aphanidermatum & P-40 & $\mathrm{PA}$ & 1994 & Lolium perenne \\
\hline P. aphanidermatum & P-41 & PA & 1991 & Lolium perenne \\
\hline P. aphanidermatum & Zen $97-71$ & $\mathrm{CA}$ & 1997 & Unknown \\
\hline P. aphanidermatum & Zen $97-375$ & Unknown & 1998 & Unknown \\
\hline P. aphanidermatum & Zen $98-5$ & $\mathrm{CA}$ & 1998 & Unknown \\
\hline P. ultimum & $\mathrm{P}-17$ & $\mathrm{PA}$ & 1996 & Chrysanthemum sp. \\
\hline P. ultimum & P-28 & PA & 1998 & Pelargonium $\times$ hortorum \\
\hline P. ultimum & P-19 & PA & 1996 & Euphorbia pulcherrima \\
\hline P. ultimum & $\mathrm{G}_{5} \mathrm{FB}_{3} \mathrm{SL} 4-14$ & FL & 2002 & Cynodon spp. \\
\hline P. ultimum & $\mathrm{G}_{6} \mathrm{FB}_{3} \mathrm{SL} 5-17$ & FL & 2002 & Cynodon spp. \\
\hline P. irregulare & $\mathrm{P}-50$ & PA & 1999 & Euphorbia pulcherrima \\
\hline P. irregulare & $72076-96$ & PA & 1996 & Euphorbia pulcherrima \\
\hline$P$. irregulare & $42130-97$ & PA & 1997 & Pelargonium $\times$ hortorum \\
\hline P. myriotylum & P-49 & PA & 1999 & Pelargonium $\times$ hortorum \\
\hline P. myriotylum & $\mathrm{P}-44$ & PA & 1999 & Pelargonium $\times$ hortorum \\
\hline P. myriotylum & P-30 & PA & 1998 & Pelargonium $\times$ hortorum \\
\hline P. torulosum & PV3 & $\mathrm{NC}$ & 2003 & Agrostis stolonifera \\
\hline P. torulosum & SV3 & $\mathrm{SC}$ & 2004 & Agrostis stolonifera \\
\hline P. volutum & PRD 48 & $\mathrm{NC}$ & 2003 & Agrostis stolonifera \\
\hline P. graminicola & UAA1 & FL & 2002 & Unknown \\
\hline
\end{tabular}

g soil, and a CEC of $13.4 \mathrm{meq} / 100 \mathrm{~g}$ soil. The turfgrasses used in this study were perennial ryegrass (cv. Integra) and creeping bentgrass (cv. Penncross). Both species were established on the test site from seed $(195.3 \mathrm{~kg} / \mathrm{ha}$ perennial ryegrass seed and $48.8 \mathrm{~kg} / \mathrm{ha}$ creeping bentgrass seed) during September 2003 and again in September 2004. The turf was mowed at $2.54 \mathrm{~cm}$ every other day with a rotary mower, and fertilized twice per year (spring and summer) with $48.8 \mathrm{~kg} / \mathrm{ha} \mathrm{N}$ per application as isobutylidene diurea (IBDU).

Prior to treatment application in 2004 and 2005 , a 9.1 by $14.6 \mathrm{~m}$ chamber constructed of an aluminum frame and covered with clear polyethylene plastic was placed over the test site. An automatic misting system designed to increase humidity and cool the turf was suspended from the chamber frame. After fungicide treatments were applied, the two open ends of the chamber were sealed with preassembled wooden frames covered with clear polyethylene plastic. Each end was equipped with a hinged window approximately $1.5 \mathrm{~m}$ above the ground that could be opened or closed to facilitate heating or cooling. Two electric heaters equipped with fans and thermostats were placed on either side of the chamber to aid in heating when night temperatures dropped below $16^{\circ} \mathrm{C}$.

Treatments included a commercial formulation of potassium phosphite (potassium phosphite-C) (Alude, Cleary Chemical Corp., Dayton, NJ); a fosetyl-Al fungicide formulated with a proprietary blue-green pigment (fosetyl-Al/pigment) (Chipco Signature, Bayer Environmental Science, Montvale, NJ); a fosetyl-Al fungicide with no pigment (fosetyl-Al) (Aliette, Bayer Environmental Science, Montvale, $\mathrm{NJ}$ ); a $1.0 \mathrm{M}$ solution of reagentgrade phosphorous acid adjusted to a $\mathrm{pH}$ of 6.2 with $10.0 \mathrm{M}$ potassium hydroxide (potassium phosphite); a solution of reagent-grade phosphoric acid adjusted to a $\mathrm{pH}$ of 6.2 with $10.0 \mathrm{M}$ potassium hydroxide (potassium phosphate); a commercial formulation of mefenoxam (Subdue MAXX, Syngenta Crop Protection, Inc., Greensboro, NC); and an untreated control. All phosphonate treatments were applied at equivalent amounts of phosphorous acid, based on the phosphorous acid equivalent listed on the Alude label and according to the molecular formula (6) and amount of fosetyl-Al listed on the Aliette and Chipco Signature labels. The rate of phosphorous acid used for all phosphonate treatments in this study was $9.6 \mathrm{~kg} / \mathrm{ha}$, and was based on the intermediate product rate (23.6 liters/ha) listed on the Alude label for Pythium diseases. Potassium phosphate was applied at $9.6 \mathrm{~kg} / \mathrm{ha}$ phosphoric acid, and mefenoxam was applied at $0.76 \mathrm{~kg} / \mathrm{ha}$. The experimental design was a split block with fungicide treatments serving as whole plots and grass species as subplots. Each treatment was replicated four times. The 
whole plots were 0.91 by $2.44 \mathrm{~m}$, and subplots were 0.91 by $1.22 \mathrm{~m}$.

Five days prior to inoculation and 3 days prior to treatment application in 2004 and 2005, thiophanate methyl (3336 F, Cleary Chemical Corp., Dayton, NJ) was applied at $9.15 \mathrm{~kg} / \mathrm{ha}$ to prevent brown patch and dollar spot caused by Rhizoctonia solani and Sclerotinia homoeocarpa, respectively.

Treatments were applied on 30 August 2004 and 18 July 2005 with a $\mathrm{CO}_{2^{-}}$ powered backpack sprayer equipped with a single boom and 11008E nozzle. Applications were made at $275 \mathrm{kPa}$ with a dilution rate equivalent to 814.8 liters $/ \mathrm{ha} \mathrm{H}_{2} \mathrm{O}$. On 31 August 2004 and 19 July 2005, the open ends of the chamber were sealed with the plastic-covered end frames.

Turf encompassing the entire $132.9 \mathrm{~m}^{2}$ test area was inoculated on 1 September 2004 and 20 July 2005 with 34.1 liters of a mycelia and rye (Secale cereal) grain slurry made from a five-isolate pool of $P$. aphanidermatum ( $\mathrm{P}-3, \mathrm{P}-20, \mathrm{P}-38, \mathrm{P}-40$, and $\mathrm{P}-41)$. The inoculum was prepared by twice-autoclaving a mixture of rye grains and water, inoculating the mixture with the $P$. aphanidermatum isolates, and allowing the mixture to become fully colonized on a laboratory bench for 5 to 7 days. Just prior to inoculation, the colonized rye grain was placed in a blender with distilled water and ground into thick slurry $(500 \mathrm{ml}$ of colonized rye grain made approximately 2.7 liters of slurry). The slurry was distributed over the test area by hand using a jar with a perforated lid. To ensure uniform coverage, four passes were made over the entire test area in different directions.

Immediately before inoculation, the misting system was activated for approximately $5 \mathrm{~min}$ and the chamber was sealed to maintain high temperatures and humidity. The misting system was activated periodically during the test period to cool turf and increase humidity. Test plots were not mowed between the day of treatment application and disease assessment (11 to 12 days after treatment).

Disease assessments were made on both grass species on 10 September 2004 (9 days after inoculation and 11 days after treatments were applied) and 29 July 2005 (9 days after inoculation and 11 days after treatments were applied). Assessments were based on the percentage of plot area showing Pythium blight symptoms (percentage of blighted turf), with $100 \%$ indicating completely blighted turf, and $0 \%$ equal to no visible blighted turf. Generally, blighted turf was severely damaged and did not recover. Data were subjected to analysis of variance and means were separated using Fisher's protected least significant difference test at $P=0.05$.

\section{RESULTS}

In vitro experiments with phosphorous acid, phosphoric acid, and mefenoxam. Phosphorous acid $\mathrm{EC}_{50}$ values for 23 isolates representing seven Pythium spp. ranged from 35.6 to $220.8 \mu \mathrm{g} / \mathrm{ml}$ (Table 2). Phosphorous acid $\mathrm{EC}_{50}$ values for the eight isolates of $P$. aphanidermatum ranged from 35.6 to $171.8 \mu \mathrm{g} / \mathrm{ml}$, with the only mefenoxam-resistant isolate showing the lowest $\mathrm{EC}_{50}$ value. P. aphanidermatum isolates were more sensitive to mefenoxam than phosphorous acid, with mefenoxam $\mathrm{EC}_{50}$ values for sensitive isolates ranging from 0.46 to $0.94 \mu \mathrm{g} / \mathrm{ml}$.

Phosphorous acid sensitivity of the other Pythium spp. tested fell within the range of $P$. aphanidermatum isolates, except for the isolate of $P$. volutum $\left(\mathrm{EC}_{50} 185.4 \mu \mathrm{g} / \mathrm{ml}\right)$ and one isolate of $P$. myriotylum $\left(\mathrm{EC}_{50}\right.$ $220.8 \mu \mathrm{g} / \mathrm{ml}$ ) (Table 2). No significant inhibition or stimulation of mycelial growth occurred for any Pythium isolate exposed to phosphoric acid (data not presented).

Suppression of Pythium blight symptoms with potassium phosphite, fosetylAl, and mefenoxam. In 2004, a treatment by turfgrass species interaction for the percentage of blighted turf was significant $(P>0.0001)$ (Table 3$)$. The interaction revealed a difference in the magnitude of percentage of blighted turf between perennial ryegrass and creeping bentgrass, with less symptom expression and greater symptom suppression with phosphonate fungicides on creeping bentgrass (Fig. 1) than on perennial ryegrass (Fig. 2).

On creeping bentgrass, no differences in percentage of blighted turf were detected among any of the fungicides used in the 2004 test (Fig. 1). On perennial ryegrass, mefenoxam provided a lower percentage of blighted turf than the potassium phosphite treatment and the potassium phosphite-C treatment; but it was not different from either fosetyl-Al treatment (Fig. 2). All phosphonate treatments provided $>89 \%$ suppression of blighted turf on perennial ryegrass and creeping bentgrass relative to the untreated control, and no differences in percentage of blighted turf were detected among any of the phosphonate treatments on either turfgrass species in 2004. The potassium phosphate treatment did not differ from the untreated control in percentage of blighted turf on either species.

In 2005, a significant treatment by species interaction occurred for the percentage

Table 2. Phosphorous acid $\mathrm{EC}_{50}$ values for seven species and 23 isolates of Pythium, and mefenoxam $\mathrm{EC}_{50}$ values for seven P. aphanidermatum isolates

\begin{tabular}{|c|c|c|c|}
\hline Pythium species & Isolate & $\begin{array}{c}\text { Phosphorous acid } \\
\text { EC }_{50}(\mu \mathrm{g} / \mathrm{ml})^{\mathrm{y}}\end{array}$ & $\begin{array}{r}\text { Mefenoxam } \\
\text { EC }_{50}(\mu \mathrm{g} / \mathrm{ml})^{\mathrm{y}} \\
\end{array}$ \\
\hline P. aphanidermatum & P-27 & 171.8 & 0.75 \\
\hline P. aphanidermatum & P-20 & 134.3 & 0.46 \\
\hline P. aphanidermatum & P-38 & 122.0 & 0.94 \\
\hline P. aphanidermatum & P-40 & 100.7 & 0.78 \\
\hline P. aphanidermatum & P-41 & 94.6 & 0.61 \\
\hline P. aphanidermatum & Zen $97-71$ & 93.7 & 0.51 \\
\hline P. aphanidermatum & Zen $98-5$ & 79.4 & 0.59 \\
\hline P. aphanidermatum & Zen $97-375^{z}$ & 35.6 & $>100$ \\
\hline P. ultimum & P-17 & 144.9 & \\
\hline P. ultimum & P-28 & 132.9 & \\
\hline P. ultimum & P-19 & 125.2 & \\
\hline P. ultimum & $\mathrm{G}_{5} \mathrm{FB}_{3} \mathrm{SL} 4-14$ & 109.2 & \\
\hline P. ultimum & $\mathrm{G}_{6} \mathrm{FB}_{3} \mathrm{SL} 5-17$ & 91.0 & \\
\hline P. irregulare & P-50 & 130.5 & \\
\hline P. irregulare & $72076-96$ & 118.1 & \\
\hline$P$. irregulare & $42130-97$ & 103.2 & \\
\hline P. myriotylum & P-49 & 220.8 & \\
\hline P. myriotylum & P-44 & 168.9 & \\
\hline P. myriotylum & P-30 & 124.2 & \\
\hline P. torulosum & PV3 & 40.3 & \\
\hline P. torulosum & SV3 & 38.7 & \\
\hline P. volutum & PRD 48 & 185.4 & \\
\hline P. graminicola & UAA1 & 143.2 & \\
\hline
\end{tabular}

${ }^{\mathrm{y}} \mathrm{EC}_{50}$ values (effective concentration that reduces mycelial growth by $50 \%$ ) were obtained by regressing relative growth against the $\log _{10}$ of phosphorous acid or mefenoxam concentration.

${ }^{z}$ Zen $97-375$ is a known mefenoxam-resistant isolate.

Table 3. Analysis of variance for percentage of blighted turf as influenced by treatments and turfgrass species

\begin{tabular}{lcccccc}
\hline & & \multicolumn{2}{c}{$\mathbf{2 0 0 4}$} & & \multicolumn{2}{c}{$\mathbf{2 0 0 5}$} \\
\cline { 3 - 4 } \cline { 6 - 7 } Source & df & $\boldsymbol{F}$ value & $\boldsymbol{P}$ value & & $\boldsymbol{F}$ value & $\boldsymbol{P}$ value \\
\hline Replication $(\mathrm{R})$ & 3 & 2.69 & 0.0769 & & 0.82 & 0.510 \\
Species $(\mathrm{S})$ & 1 & 41.11 & 0.0077 & & 7.43 & 0.0722 \\
$\mathrm{R} \times \mathrm{S}$ & 3 & 1.26 & 0.3164 & & 1.95 & 0.1574 \\
Treatment $(\mathrm{T})$ & 6 & 115.39 & $<0.0001$ & & 30.22 & $<0.0001$ \\
$\mathrm{~T} \times \mathrm{S}$ & 6 & 9.61 & $<0.0001$ & & 3.43 & 0.0195 \\
\hline
\end{tabular}


of blighted turf $(P=0.0195)$ (Table 3$)$. As in 2004 , the interaction indicated a difference in the magnitude of percentage of blighted turf between perennial ryegrass and creeping bentgrass. Greater disease symptom suppression with phosphonate fungicides occurred on creeping bentgrass (Fig. 3) than on perennial ryegrass (Fig. 4).

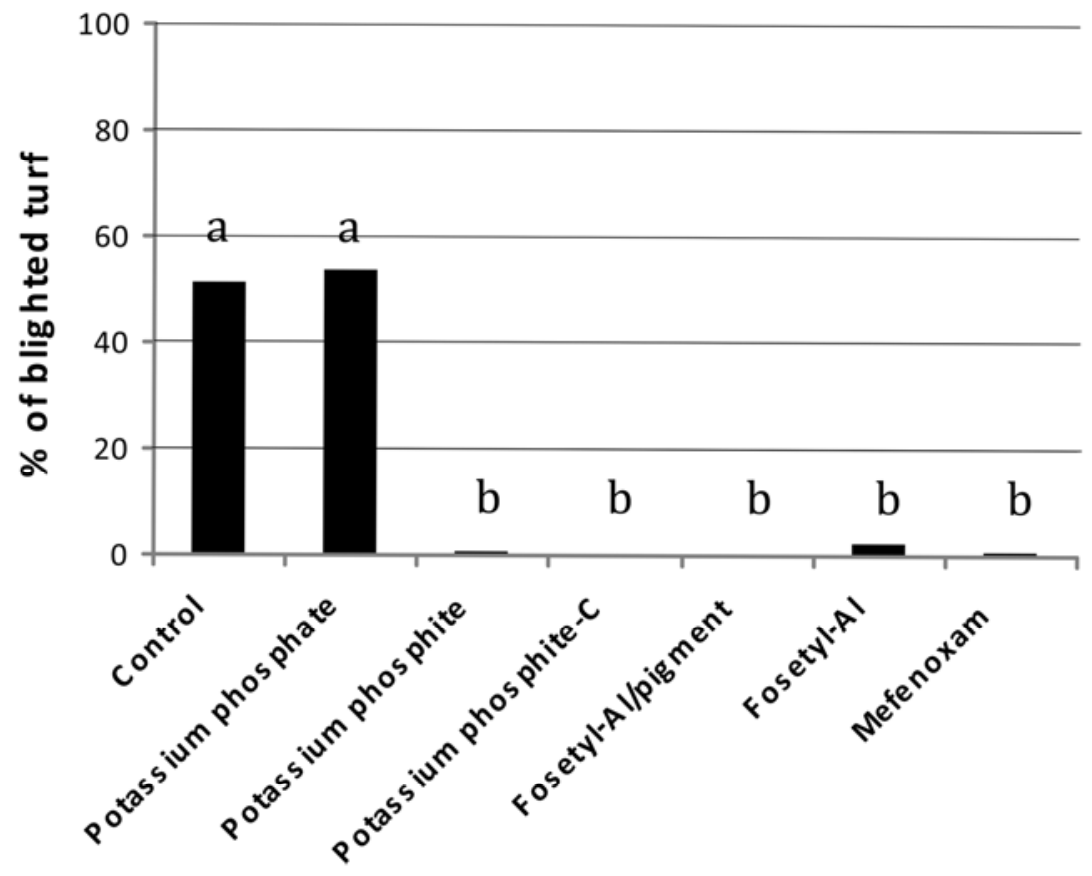

Treatments

Fig. 1. Effect of phosphonate fungicides on Pythium blight development of creeping bentgrass cv. Penncross in 2004, expressed as percentage of blighted turf. Potassium phosphite-C is a commercial formulation of potassium phosphite (Alude), fosetyl-Al is a commercial formulation fosetyl-Al (Aliette), and fosetyl-Al/pigment is a commercial formuation of fosetyl-Al and a propietary blue-green pigment (Chipco Signature). Bars with the same letter are not significantly different at $P=0.05$.

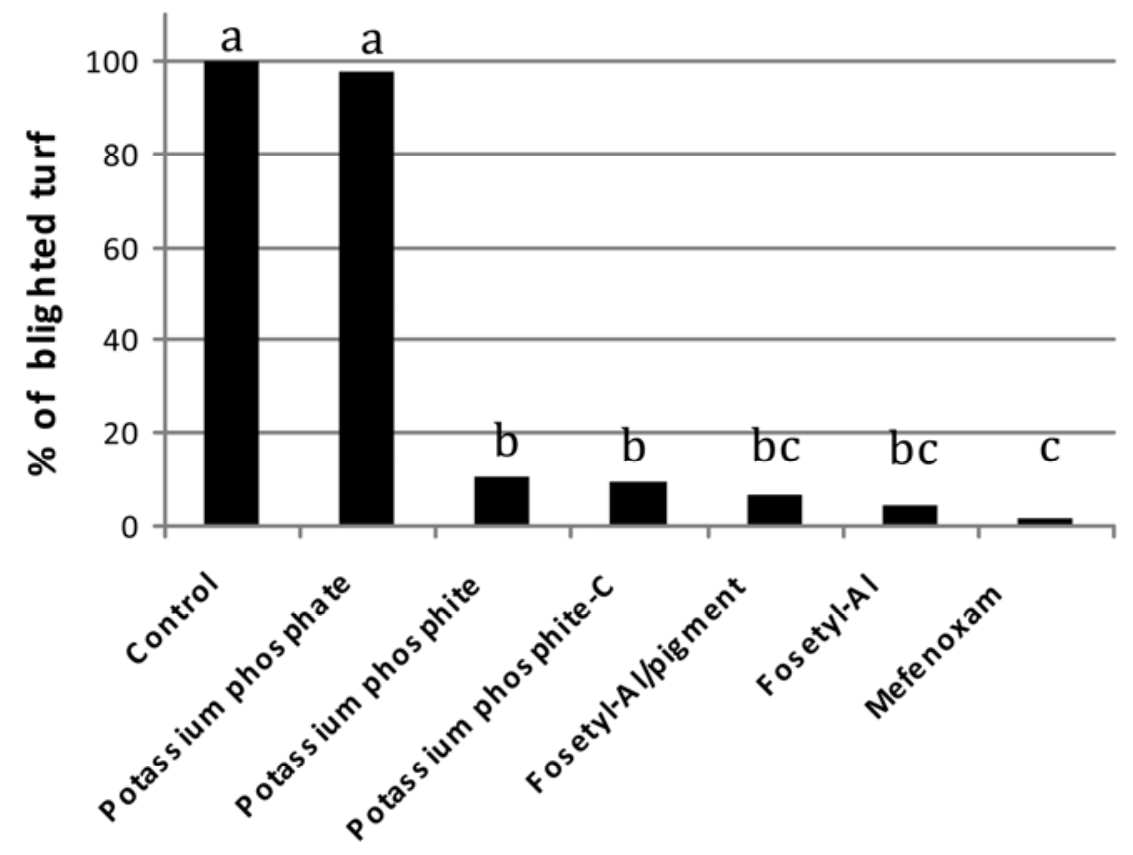

\section{Treatments}

Fig. 2. Effect of phosphonate fungicides on Pythium blight development on perennial ryegrass cv. Integra in 2004, expressed as percentage of blighted turf. Potassium phosphite- $\mathrm{C}$ is a commercial formulation of potassium phosphite (Alude), fosetyl-Al is a commercial formulation fosetyl-Al (Aliette), and fosetyl-Al/pigment is a commercial formuation of fosetyl-Al and a propietary blue-green pigment (Chipco Signature). Bars with the same letter are not significantly different at $P=0.05$.

All phosphonate treatments and mefenoxam provided a lower percentage of blighted turf than the untreated control and potassium phosphate treatment on creeping bentgrass and perennial ryegrass. Although suppression of Pythium blight symptoms with the phosphonate treatments was not as pronounced in 2005 as in 2004, no differences in percentage of blighted turf occurred among these treatments. On creeping bentgrass, the mefenoxam treatment showed reduced percentage of blighted turf compared to the potassium phosphite-C treatment, but was not different from the fosetyl-Al, fosetyl-Al/ pigment, and potassium phosphite treatments (Fig. 3). On perennial ryegrass, mefenoxam provided greater suppression of Pythium blight symptoms that all other treatments (Fig. 4).

\section{DISCUSSION}

Inhibition of mycelial growth, expressed as phosphorous acid $\mathrm{EC}_{50}$ values, for 23 isolates representing seven Pythium spp. ranged from 35.6 to $220.8 \mu \mathrm{g} / \mathrm{ml}$. Although the degree of sensitivity of Pythium isolates to phosphonate fungicides was not determined in vivo, blighting caused by $P$. aphanidermatum isolates used to inoculate the field study $\left(\mathrm{EC}_{50}\right.$ values ranging from 94.6 to $134.3 \mu \mathrm{g} / \mathrm{ml}$ ) was suppressed with phosphonate fungicides at rates listed on the fungicide labels. This is in agreement with a report by Sanders et al. (14) in which blighting of creeping bentgrass caused by a $P$. aphanidermatum isolate with an $\mathrm{EC}_{50}$ value of $275 \mu \mathrm{g} / \mathrm{ml}$ was suppressed using $2.4 \mathrm{~g} / \mathrm{m}^{2}$ of Aliette $80 \mathrm{~W}$. Presumably, disease-causing abilities of all $P$. aphanidermatum isolates within the range of $\mathrm{EC}_{50}$ values found in our study can be suppressed with label-prescribed rates of phosphonate fungicides.

To date, no field resistance or reduced sensitivity of Pythium spp. to phosphonate fungicides has been reported. However, three $P$. aphanidermatum isolates exposed to a chemical mutagen had $\mathrm{ED}_{50}$ values ranging from 3,000 to $4,700 \mu \mathrm{g} / \mathrm{ml}$, and two of the isolates were completely insensitive to the Aliette $80 \mathrm{~W}$ applied to creeping bentgrass at 2.4 and $3.7 \mathrm{~g} / \mathrm{m}^{2}$ in pot studies (14). Two of the P. aphanidermatum isolates used in our in vitro study (PA 20 and PA 27) were isolated before phosphonate fungicides were used on golf courses; thus, the $\mathrm{EC}_{50}$ values of 134.3 and $171.8 \mu \mathrm{g} / \mathrm{ml}$ for these isolates can serve as baseline values from which to compare $P$. aphanidermatum isolates where reduced sensitivity is suspected. We found no evidence for making assumptions on reduced sensitivity for any of the other Pythium spp. used in this study.

Few studies have been conducted to determine if differences in sensitivity to phosphonate fungicides occur among various Pythium spp. Fenn and Coffey (11) reported significant differences in growth 
among four Pythium spp. in response to phosphorous acid on CMA. However, the authors used only one isolate to represent each species and thus did not examine intraspecies variability. Because only a limited number of isolates of individual Pythium spp. were used in our study, no meaningful conclusions can be drawn concerning sensitivity differences among species. However, in some cases, the range of $\mathrm{EC}_{50}$ values for isolates of one species overlap with those for other species, indicating that intraspecies variation should be considered if attempting to distinguish phosphorous acid sensitivity among $P y$ thium spp.

Comparisons of phosphorous acid $\mathrm{ED}_{50}$ values from different studies should be interpreted with caution due to differences in experimental methods. Studies using phosphonate fungicides and phosphorous acid have revealed that factors such as phosphate concentration in media, $\mathrm{pH}$ of the medium, and active ingredient (potassium phosphite versus fosetyl-Al) can influence the growth response of certain fungi $(1,2,11)$. In the present study, phosphorous acid was adjusted to a $\mathrm{pH}$ of 6.2 and amended into CMA so that we could attempt a reasonable comparison of our findings with studies using similar methods $(11,14)$. Results from our study would likely change if experiments were performed using media other than CMA or if the $\mathrm{pH}$ of the phosphorous acid solution was significantly different from 6.2.

Results of our field study using commercial phosphonate fungicides and a solution of reagent-grade phosphorous acid with no formulation enhancements at equivalent rates of phosphorous acid revealed no differences in percent blighting among phosphonate treatments in either year of the study, regardless of active ingredient, formulation, or turfgrass species. These results are similar to other studies in which no differences in Pythium blight suppression were found among commercial fungicides containing fosetyl-Al or potassium phosphite as the active ingredient $(9,10,17,19)$. In studies where differences in Pythium blight efficacy were found among certain phosphonate products, the reason may have been due to products being applied at different rates of phosphorous acid $(20,21)$.

The findings from our field study may not necessarily hold for other diseases or other hosts. In a study on Persica indica, buffered phosphorous acid provided better control of stem infection caused by Phytophthora citricola compared with fosetylAl when both treatments were applied at equal concentrations of phosphorous acid (11). Cook et al. (7) found that fosetyl-Al formulated with a proprietary blue-green pigment (Chipco Signature) provided better suppression of anthracnose basal rot in putting greens compared with other phosphonate fungicides applied at equivalent rates of phosphorous acid. The fact that this formulation suppressed anthracnose symptoms and another fosetyl-Al product did not, indicates that formulation differ- ences may account for the improved anthracnose control. The blue-green pigment associated with the fosetyl-Al may have an indirect beneficial effect on anthracnose

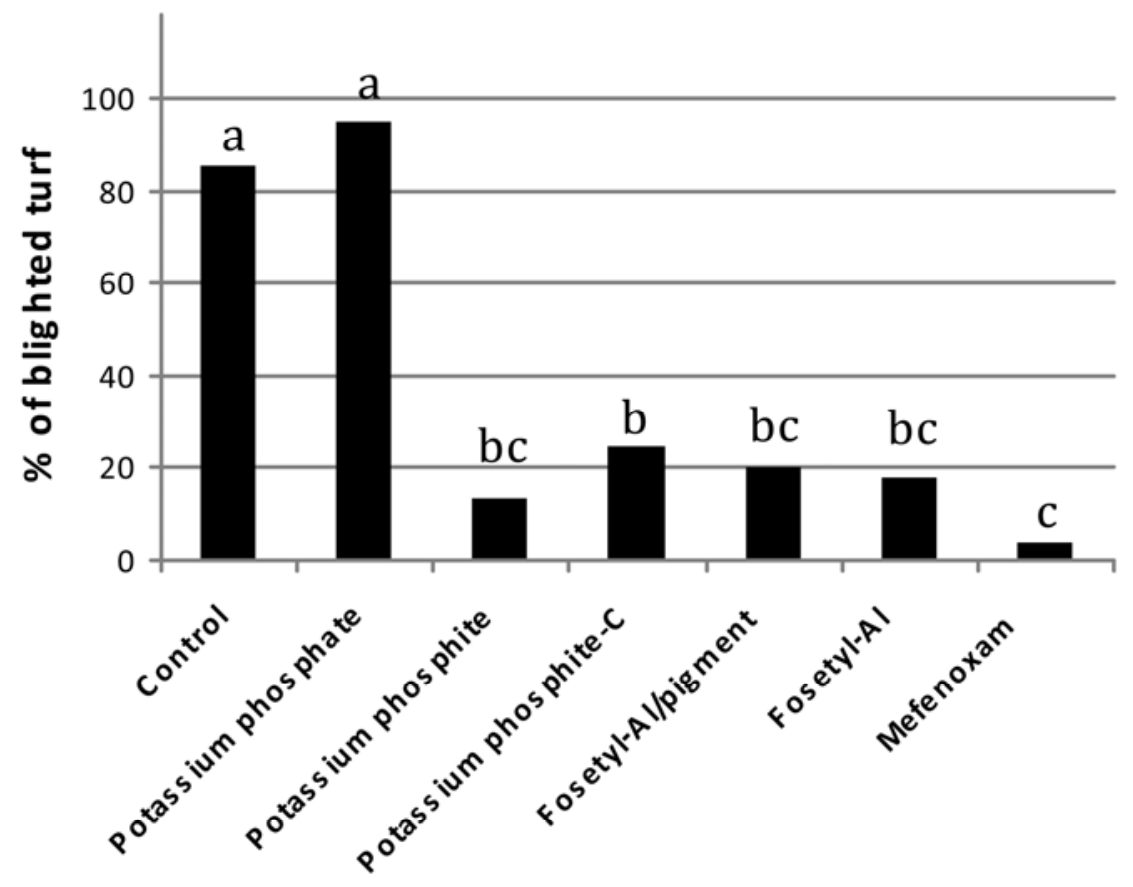

Treatments

Fig. 3. Effect of phosphonate fungicides on Pythium blight development of creeping bentgrass cv. Penncross in 2005, expressed as percentage of blighted turf. Potassium phosphite-C is a commercial formulation of potassium phosphite (Alude), fosetyl-Al is a commercial formulation fosetyl-Al (Aliette), and fosetyl-Al/pigment is a commercial formuation of fosetyl-Al and a propietary blue-green pigment (Chipco Signature). Bars with the same letter are not significantly different at $P=0.05$.

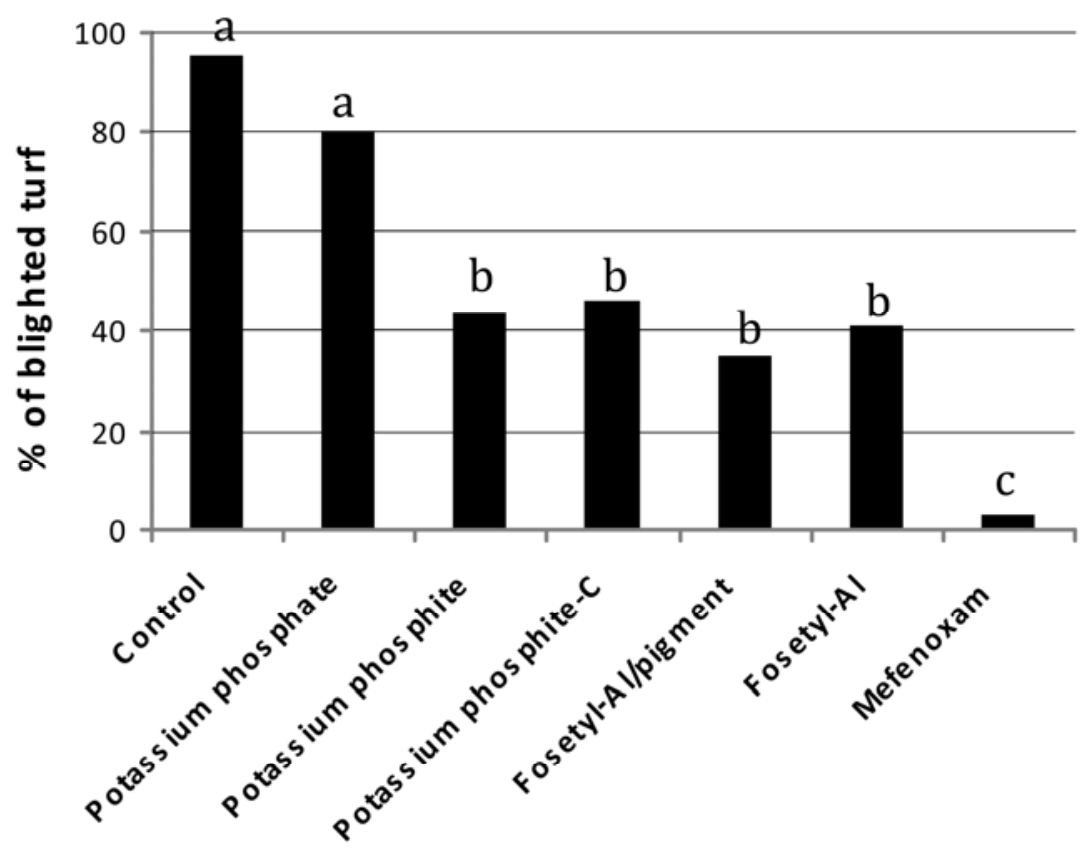

Treatments

Fig. 4. Effect of phosphonate fungicides on Pythium blight development on perennial ryegrass cv. Integra in 2005, expressed as percentage of blighted turf. Potassium phosphite- $\mathrm{C}$ is a commercial formulation of potassium phosphite (Alude), fosetyl-Al is a commercial formulation fosetyl-Al (Aliette), and fosetyl-Al/pigment is a commercial formuation of fosetyl-Al and a propietary blue-green pigment (Chipco Signature). Bars with the same letter are not significantly different at $P=0.05$. 
suppression, perhaps by enhancing disease resistance mechanisms or shielding turfgrasses from debilitating environmental stresses which may predispose turfgrass to anthracnose $(3,24)$.

In conclusion, results of this study demonstrate there is little difference between potassium phosphite and fosetyl-Al fungicides with respect to suppression of Pythium blight when applied prior to symptom development at similar rates of phosphorous acid. However, the degree of Pythium blight suppression with phosphonate fungicides may be greater on creeping bentgrass than on perennial ryegrass. Practitioners should be able to successfully use either type of active ingredient preventatively in their Pythium blight management programs on perennial ryegrass and creeping bentgrass. Although phosphorous acid inhibited all Pythium spp. examined in the in vitro study, little information exists on suppression of Pythium diseases other than Pythium blight. More research is needed on the efficacy of phosphonate fungicides on Pythium root rot and dysfunction of turfgrasses, and how the respective pathogens are influenced by phosphorous acid.

\section{ACKNOWLEDGMENTS}

A portion of this work was funded by the Pennsylvania Turfgrass Council, Bayer Environmental Science, and Cleary Chemical Corporation. We thank the following individuals for supplying isolates used in this study: J. Kerns, G. Moorman, C. Stiles, L. Tredway, and W. Uddin. We also acknowledge M. Agnew of Syngenta Professional Products for providing technical-grade mefenoxam, and M. Soika for assisting with preparation and distribution of inoculum, as well as assembly of the Pythium chamber.

\section{LITERATURE CITED}

1. Abu-Jawdah, Y. 1983. Cell swellings of Colletotrichum lindemuthianum (Sacc. \& Magn.) Bri \& Cav. induced by treatment with phosethyl-Al. Parasitica 39:3-8.

2. Barchietto, T., Saindrenan, P., and Bompeix, G. 1989. Characterization of phosphonate uptake in two Phytophthora spp. and its inhibition by phosphate. Arch. Microbiol. 151:54-58.

3. Burpee, L. L. 2005. Sensitivity of Colletotrichum graminicola to phosphonate fungicides. Int. Turfgrass Soc. Res. J. 10:163-169.

4. Burpee, L. L., Stephens, S. L., and MartinezEspinoza, A. D. 2005. Effect of fungicides on Pythium blight of tall fescue, 2004. Fungic. Nematicide Tests 60:T045.

5. Coffey, M. D., and Joseph, M. C. 1985. Effects of phosphorous acid and fosetyl-Al on the life cycle of Phytophthora cinnamoni and P. citricola. Phytopathology 75:1042-1046.

6. Cohen, Y., and Coffey, M. D. 1986. Systemic fungicides and the control of oomycetes. Annu. Rev. Phytopathol. 24:311-338.

7. Cook, J., Landschoot, P. J., and Schlossberg, M. 2006. Phosphonate products for disease control and putting green quality. Golf Course Manag. 74:93-96.

8. Datnoff, L., Cisar, J., Rutherford, B., and Williams, K. 2001. Effect of fungicides on Pythium blight development on Poa trivialis overseeded into a bermudagrass green, 2000. Fungic. Nematicide Tests 57:T11.

9. Datnoff, L., Cisar, J., Rutherford, B., Williams, K., and Park, D. 2004. Preventative effect of fungicides on Pythium blight development on Poa trivialis, 2002. Fungic. Nematicide Tests 59:T040.

10. Datnoff, L., Cisar, J., Rutherford, B., Williams, K., and Park, D. 2005. Effect of fungicides and other prophylactic treatments on Pythium blight development on Poa trivialis, 2004. Fungic. Nematicide Tests 60:T033.

11. Fenn, M. E., and Coffey, M. D. 1984. Studies on the in vitro and in vivo antifungal activity of fosetyl-Al and phosphorous acid. Phytopathology 74:606-611.

12. Guest, D., and Grant, B. 1991. The complex action of phosphonates as antifungal agents.
Biol. Rev. 66:159-187.

13. Nutter, F., and Cole, H., Jr. 1983. Disease forecasting system for warm weather Pythium blight of turfgrass. Plant Dis. 67:1126-1128.

14. Sanders, P. L., Coffey, M. D., Greer, G. D., and Soika, M. D. 1990. Laboratory-induced resistance to fosetyl-Al in a metalaxyl-resistant field isolate of Pythium aphanidermatum. Plant Dis. 74:690-692.

15. Sanders, P., Houser, W. J., and Cole, H., Jr. 1983. Control of Pythium spp. and Pythium blight of turfgrass with fosetyl aluminum. Plant Dis. 67:1382-1383.

16. Smiley, R. W., Dernoeden, P. H., and Clarke, B. B. 2005. Compendium of Turfgrass Diseases, 3rd ed. American Phytopathological Society, St. Paul, MN.

17. Soika, M. D., and Tredway, L. P. 2007. Evaluation of fungicides for control of Pythium blight and gray leaf spot in tall fescue landscapes, 2006. Plant Dis. Manag. Rep. 1:T032.

18. Stiles, C. M., Datnoff, L. E., and Rayside, P. A 2007. Pythium spp. isolated from bermudagrass during overseed transitions in Florida and pathogenicity of Pythium irregulare on Poa trivialis. Plant Dis. 91:1237-1244.

19. Uddin, W., Shelton, J., and Kish, D. 2002. Management of Pythium foliar blight with fungicides on perennial ryegrass, 2001. Fungic. Nematicide Tests 57:T40.

20. Uddin, W., Soika, M. D., Shelton, J., and Soika, E. L. 2003. Control of Pythium foliar blight on perennial ryegrass, 2002. Fungic. Nematicide Tests 58:T056.

21. Uddin, W., Soika, M. D., Soika, E. L., and Francl, A. 2004. Pythium foliar blight control with the use of fungicides, 2003. Fungic. Nematicide Tests 59:T037.

22. Uddin, W., Soika, M. D., Soika, E. L., and Francl, A. 2005. Control of Pythium foliar blight with the use of fungicides, 2004. Fungic. Nematicide Tests 60:T051.

23. Vargas, J. M., Jr. 1994. Management of Turfgrass Diseases, 2nd ed. Lewis Publishers, Boca Raton, FL.

24. Vincelli, P., and Dixon, E. 2005. Performance of selected phosphite fungicides on greens. Golf Course Manag. 73:77-81. 